\title{
COVID-19 -global transition to a new architecture and urban development paradigm of the environment?
}

\author{
Galina Aidarova ${ }^{1 *[0000-0001-7469-8120]}$, and Aidar Aminov ${ }^{10000-0002-1204-5164]}$ \\ ${ }^{1}$ Kazan State University of Architecture and Engineering, 420043, Zelenaya st., Kazan, Russia
}

\begin{abstract}
New trends in the social life at crucial points mean applying to the past experience and looking for new development models. COVID-19 has marked a global transition to a new architecture and urban planning paradigm of the environment in accordance with the sanitary, hygienic requirements and rational forms. In accordance with the current challenges it becomes necessary to reevaluate the concepts of urbanism and disurbanism redefining urban planning, existing typology, structural and functional organization as well as to search for new ways of architecture and urban development. Urban structures and sociology are expected to be reconsidered leading to reduced capacity of all public buildings, disappearance of some of them and replacement by recreation zones. Inexhaustible ideas and resources of past design approaches may be featured in the buildings styles. We could predict appearance of significant signs of new ethics in the new aesthetics which will mark the arrival of the third global «superstyle» which features have been already seen in the rigid construction approaches, in the social movements activities. Methods of architecture education are expected to be modified: in particular, the importance of advanced techniques in the educational process will increase and teamwork in the architecture projects will became vital.

Keywords: Theory and history of architecture, new paradigm of the living environment, new architecture typology, architecture and urban development experience, past time development style resources, new ethics and aesthetics.
\end{abstract}

\section{Introduction}

The future has come unexpectedly and unpredictably. Recently theoreticians of architecture have been concerned about enhancing comfort and quality of living satisfying the rising public demands.

Paradigm of the architectural environment formed in XX century evolved from functionalism to the environment approach, then to the ecological sustainability principles. In XIX century William Morris predicted negative impact of the functionalism on the living environment design. In XX such an issue was raised by the architects Wright F.L, Eimar S., Howard E, Garnier T., Daniel Koch, Foster N., B. Cannon Ivers, Jan Gehl, Ikonnikov A.V.,

\footnotetext{
${ }^{*}$ Corresponding author; aidagalnik@mail.ru
} 
Hugo Alvar Henrik Aalto, Le Corbusier, Beatriz Colomina. In addition to the existing challenges such as nuclear threat, technological and ecological catastrophes there have appeared a variety of virus contamination. Covid-19 has tasked architectural theory and practice with arranging living space in accordance with the global danger conditions.Regardless of an epidemic causes and potential of future virus attacks, the questions of survival, reviewing and optimization of the current architectural space to be the most appropriate living environment have been placed high on the agenda. We are still not aware of the epidemic impact being unprepared for the pure rationality, limitations in our conventional forms of social and private life.

Boundaries of Research are defined by modern social phenomena, theories of architecture, typological and stylistic transformations of the architectural environment.

The purpose of the article is a theoretical prediction of new approaches to the organization of the architectural environment in the context of current and future epidemiological threats.

The objectives of the study are to analyze current problems and trends, taking into account the factor of COVID-19, a radical transformation of functional, typological and aesthetic characteristics.

The study revealed the tendencies of the global transition to a new paradigm of the spatial organization of the environment based on: «neo-disurbanism» (mainstreaming of a garden city), new models of cities (mainstreaming of metabolism); «Post New Brutalism» (the third global «super style»); leading methods in training of architects (cognitive approach, self-development), etc.

\section{Materials and methods}

Research methods: theoretical and project resources, historical and architectural and stylistic methodology, generalization and interpretation techniques. The study materials include various publications on ecology issues, architectural typology, architecture theory, architectural space and styles.

\section{Results}

In the historical aspect the current global danger has reached an unprecedented level. An epidemic had never occurred in all the biggest continents concurrently.Past major catastrophes were associated with fires, wars, earthquakes, volcanic eruptions, local epidemic. They all had influence on the dynamic, structure and typology of cities. London in 1854: cholera epidemic due to the contamination of drinking water with sewage water, the problem was solved by sewage system construction. The 1812 Fire of Moscow, The Great Chicago Firein 1871 led to city centres development.

In XX century by the means of science there have been eradicated smallpox, tuberculosis, cholera and other diseases. Medicine seemed to be omnipotent. Sanitary requirements and «proper cities» provided certainty in a trend away from disurbanization towards urbanization. In the famous book by Beatriz Colomina the the author traces works of outstanding architects- modernists (Le Corbusier, Ludwig Mies van der Rohe, Hugo Alvar Henrik Aalto) as an improvement of the environment by means of architecture complying with hygiene requirements: white colour, minimal decoration, large glassing, flat roofs- solariums. (Colomina 2019) [1]. Conceptual model of English Garden-City for three million people by Le Corbusier and Athens Charter demonstrated a new direction of the development. That paradigm showed sustainability throughout XX century. Meanwhile, 
settlement schemes, megalopolises population concentration have been formed without considering global epidemic. Existing settlement models, typology of residential and public complexes as well as applicable sanitary standards for their design may endure significant change. Obviously, development direction will be tied with the new values -striving for sanitary, ecological and technological balance.

By the late XX century the ecological problems, resource saving and heritage preservation trendshad revealed the necessity in the change of the development paradigm, new ways and models contributing to the civilization sustainability [2, 3]. At the moment the humanity has been facing the global problems. For the first time an epidemic affects the whole built environment paradigm starting from settlement and ending with architecture and urban planning typology and style which requires redefining typology of residential, public, industrial and religious buildings [4].

At breaking points in the social development history solutions tend to be found while looking into the future as well as referring to the past. On one hand, undoubtedly, new ideas and new civilization paradigm are needed. On the other hand, those unappreciated development ideas of the past should be analyzed since no idea is ever lost, it appears and actualizes in due time.

\subsection{New disurbanizm}

What could be the first steps towards the optimization of the existing cities and architecture typology? Architectural practice may use and has used ideas implemented in XX century and ideas prompted by life challenges and necessity to tackle the problems in practice [5, 6]. Meanwhile architectural and urban development theories should create long-term built environment development criteria taking in account new future directed technologies.

Which pastutopian visions now seem prophetic and realistic? Doubts about the values of the technological progress coming with XX century followed by the nature and natural resources destruction were expressed by William Morris [7]. F.L. Wright, who was a consequent disurbanist, created utopian models of future cities (Fig.1) which can be of interest at present.

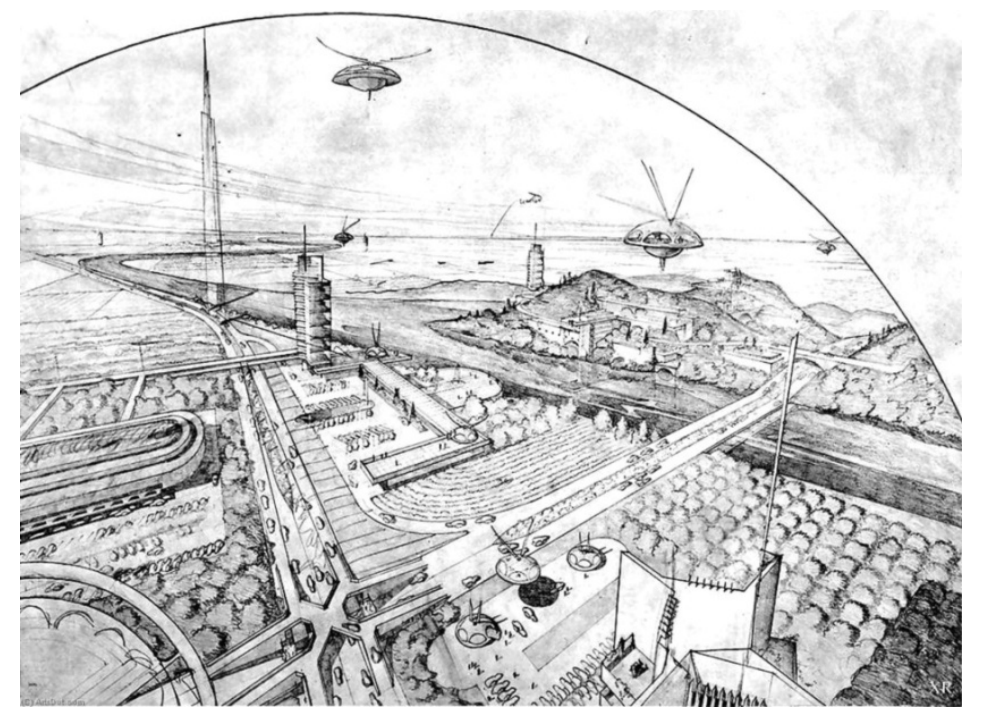

Fig. 1. Broadacre City, architect F. L. Wright, 1932, (Wright 2016). 
Disurbanismis now high on the agenda of the architecture theory and practice and development perspectives $[8,9]$. There may be positive consequences such as migration from megapolises to the abandoned villages and small towns in Leningrad, Moscow, Tula, Rostov and Tambov regions. In theory there must be alteration to the settlement paradigm, new regulations and standards on design and construction will appear. New town models will have disurbanizm and independent ideas, the principles of functional zoning will be actualized. This is going to be a different disurbanizm - a New Disurbanizm based on the contemporary technologies (Fig. 2).

It should be expected that healthcare, family values, ethnic and national traditions will be of high priority. Quality of life will alter in accordance with understanding comfort as minimizing demands, promoting physical activity and culture. Importance of participation in all the social activities will increase.

Garden-City idea has been implemented in Turkey. University students in Ankara planted thousands of trees to heal the city. The ideas spread throughout the world, since then billions of trees have been planted and the trend continues. According to the media the share oftown greening social movement is expanding in various countries such as Turkey, China, India. There have been planted 11 million of trees in 81 towns in Turkey; 156 hectares of land were planted in Indonesia.City centres population dilution and cities expansion will occur due to the city centre and the outskirts green zones enlargement [10].

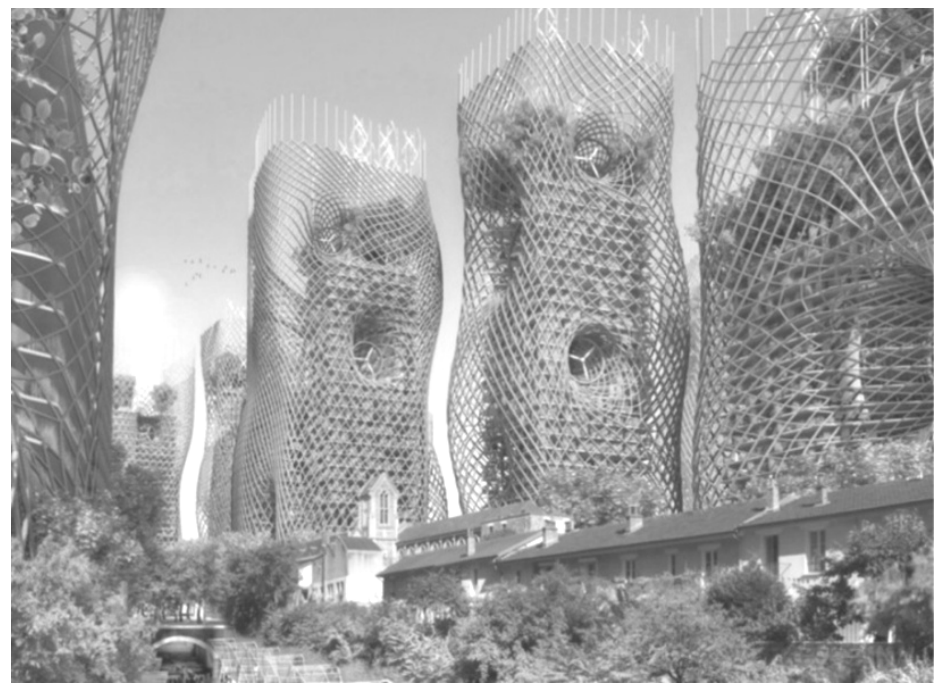

Fig. 2. Project «PARIS SMART CITY 2050», architect V. Callebaut, 2015 image from the official website of the architect: https://vincent.callebaut.org/.

In large cities the Soviet Union experience in standardizedtown-planning could be reconsidered and implemented. Small towns and the rural areas with the healthier environment and where migrants from large cities will movein search of farming opportunities will soon require contemporary social infrastructure and communication facilities [11]. That wills raiseaquestionabout countryside settlements maintenance schemes depending on the households model and number and aiming to transform current forms of maintenance. On having Internet connection provided it becomes possible to tackle other issues such as food supply, on-line learning and work process. Subsistence agriculture and local farms will boost the country economy in the course of self-development. However, in the postCovidperiodthere may befewer jobs, acting marginalized groups, further social segregation, tightening social control regulating all the aspects of social life. 


\subsection{New typology}

High priority given to well-being, diet, employment will lead inevitably to reducing not essential demands, leisure activities will become more practical and will include farming, gardening and subsistence agriculture.Residential construction will require alteration in the typology of the premises and residential apartments concept due to the additional safety requirements applied to the residential complexes [12]. Some office, art and craft in work will be moved to the residential zone. New forms of apartment complexes based on the hybrid technologies will appear. Entrances, halls, stair cases and lifts will be considered «dirty zones». Exterior and interior surfaces must comply with sanitation requirements. Self-service sanitation mobile units will become mandatory in the apartment complexes $[13,14]$.

New forms of distant work, education, leisure will be requested and live communication will become a great value. We should expect that current schemes and forms of social service will be altered leading to all the public buildings capacity reduction, disappearance of some of them and replacement by recreation zones.

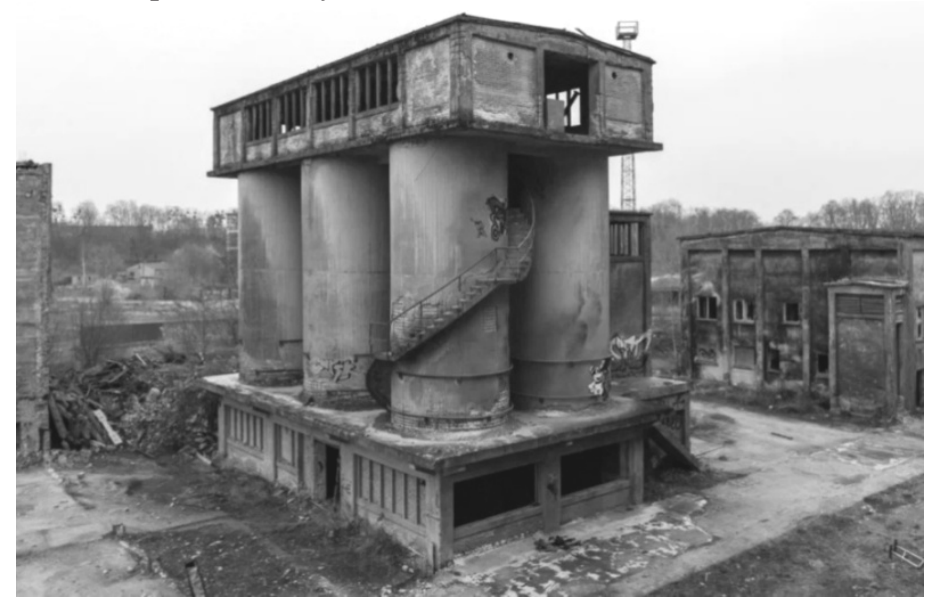

Fig. 3. The building of an abandoned chemical plant in Rüdersdorf, Berlin, 1899. image source: https://www.abandonedberlin.com/chemiewerk-ruedersdorf/.

Changes in the construction technology could be associated with the rational solutions and aimed mainly at revitalization of abandoned industrial and public complexes unappreciated in new conditions. (Figs. 3, 4). 


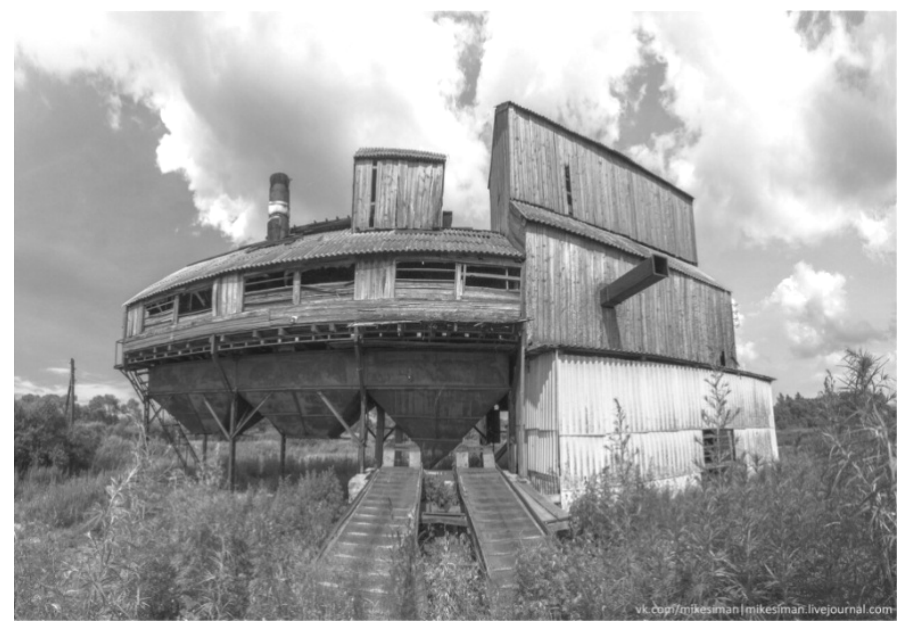

Fig. 4.Abandoned grain cleaner, Khabarovsk Territory, photo by M. Simanchuk, image source: https://mikesiman.livejournal.com/49159.html.

Sport centres may be converted into recreation zones or demolished. In general, flexible ability to respond to the current and future uncertain threat will be essential feature. Any projects with unreasonable material investments should be closed down. Live TV broadcast of the Vienna Philharmonic concert performed on 2 January 2021 is an example of the changing world. The orchestra consisted of 100 musicians was playing Straus music in the empty theatre. The on-line audience from all over the world could applaud and leave their comments. Worldwide Internet connection makes it possible to attend such concerts and concerts at Bolshoi Theatre or Milan Opera.

During disasters religious values are being instilled. In $\mathrm{XX}$ century religion was eliminated from the global social issues by the science [15]. Survival challenges may require high level of social morality and ethics and need for the current and new types of religious architecture [16].

\section{Discussion}

\subsection{Ethics and aesthetics}

The results haven't direct comparison and are notable for analyzing interdisciplinary and special aspects. Existing studies cover aspects of the problems of interest: architecture and ecology (Eimar S, B., Kolomina, Zhuikov S.S., A. Byers, P. Stapleton, D. Torben), urbanisms (J.G. Mastalerchik), urban landscapes (Cannon BI), architectural education (Metlenkov N. F). The most interesting are the issues of the development of architectural styles, ethics and aesthetics of the post-Covid period, which still not popular surround researchers. Any new phenomenon is born long before its manifestation. High-tech roots can be found in XIX century technological achievements: Cristal Palace (1851), The Galerie des Machines (1889), Eiffel Tower (1889); deconstructivism roots - in the XVIIIIX centuries romanticism: artificial ruins in the European park complexes; and in the Russian constructivists (I. Leonidov, El Lisitskiy, V. Tatlin, V. Shukhov).In New Brutalism ideas there can be seen intention to escape from the «pseudo aesthetics» to the rational aesthetics and ethics. Smithson's and Louis Kahn aesthetics had its continuation emerging in lofts, interior and exterior solutions. In the same manner, theoretical concept could be 
grounded on ideas and experience of Metabolists in the 1960s who laid the foundation for flexible structures under uncertainty of the designed spaces purpose [17].

Seeds of the future stylistic concept and solutions for formation in the architectural theory and practice must be found in the present styles. It is obvious that unlike different forms of postmodernism, deconstructivism, regionalism, there are not only opposite styles associated with eco-architecture but some other trends caused by the interest in the vernacular architecture («architecture without an architect») (Figs. 5, 6) spontaneous industrial construction and variety of architecture with no pursuing aesthetics. Perhaps they have a potential in a new ethics development associated with new «Post New Brutalism», firmer formation concept. Revitalization of the current residential, industrial and public buildings remains an important feature (Fig.7).

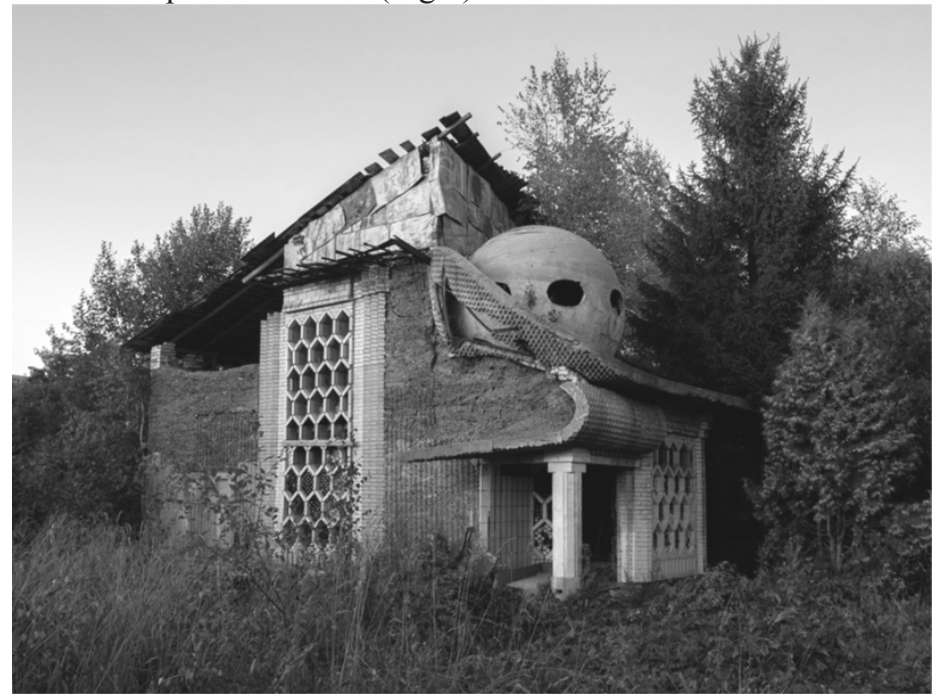

Fig. 5. Abandoned residential building, designed and built by O. Arkhipov, Vysokoklyuvoy village, Leningrad region, 70s-90s XX century, photo by E. Tsvetkov, image source: https://paperpaper.ru/photos/v-lenoblasti-est-zabroshennyj-dom-s-sha/.

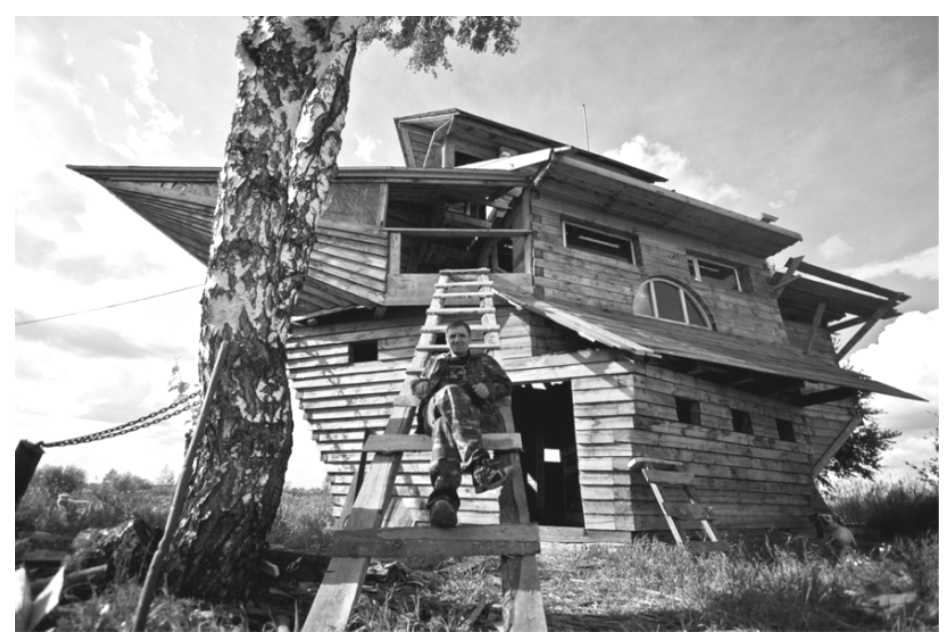

Fig. 6. Private residential house-ship, author and owner N. Orekhov, Borovoy village, Kemerovo region.image source: https://zen.yandex.ru/media/aleksandrov/i-prisnitsia-je-takoe-domkorablrukami-liubitelia-iz-naroda-5da440f7f557d000ae05c074. 
According to the newest research on the term «Global Style» and Khan-Magomedov concept of the two universal shape-forming systems: classicism and «contemporary trend» as well as on the idea of «the third global «superstyle» expressed by L. P. Kholodova, they all associated with some global determinates such as social system, manufacture principles, technology, science and human-environment interaction.

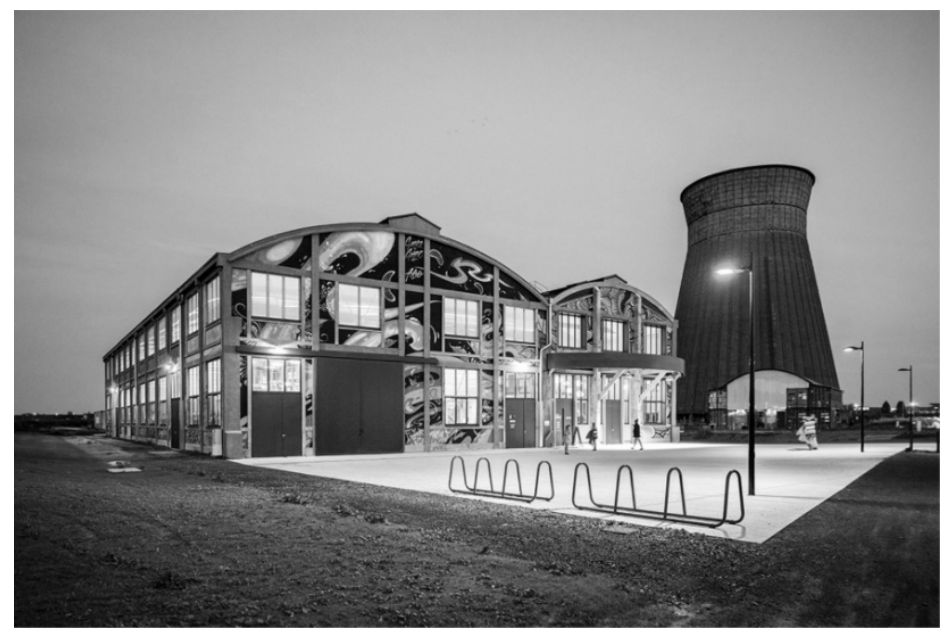

Fig. 7.Reconstruction project of the former workshop of a metallurgical plant in Normandy into a modern public space Grande Halle, architect S. Eimar, 2019, photo by Cyrus Cornut.

The first global «superstyle» refers to the ancient period of the agriculture and craftsmanship and the New time period with manufactures. The second global style associated with industrial, scientific and informational system of production. The second global style will be replaced by the third global «superstyle» [18].

What it could be if it is unlike both, the first and the second? Is this true? The time will tell! We can assume that the new determinates such as alterations in the social system and families, innovative technology, human-environment interaction crisis may lead to the emergence of the third global «superstile» which may have many unexpected and unpredictable elements related to the post Covid period implications.

Perhaps, the third global «superstyle» concept will reveal post New Brutalism trends in the architectural structures with the aesthetics based on the rough beauty of the worn materials, imprecise joints, intentional lack of decoration, spontaneous composition of the secondary-use elements.

\subsection{Education}

Education process in the architecture traditionally involved personal contacts. Under the current circumstances we should expect emergence of new education standards including on-line lectures, distant learning and training as well as degree project work. Therefore new educational principles will be defined. Teamwork within a greater framework, dynamic forms of temporary teams created to complete a specific task and many other features yet unknown will be important elements of an architect work.

Personnel training techniques undoubtedly will alter. In particular, self study performance will be of high importance. Self-development approach to the architectural education has been offered by N. F. Metlenkov. In paradigmatic terms, the method of development in the architecture theory and practice may lead to the new twist in the understanding of the development trends taking in account new social events [19]. 
In post Covid period public places design will require new approaches depending on the dynamics of the social process. Methodical approach of the cognitive urbanism developed by Frasheninnikov A.V and based on the cognitive sociology including environmental behavior, scenario and usual social life activities and relations which are used to define optimum features of the environmental design. Actual use of the public areas is now seen as a spatial structure created by the social activity [20].

\section{Conclusion}

To conclude we can summarize that we are on the brink of the world global change which will be completed by the end of XXI century. Current and future challenges are caused by the technological progress acceleration which is in the conflict with the fundamental Laws of Nature. The task of ceasing and swinging the current development trend, finding a bifurcation point and a new direction is the global community challenge. Architecture plays an important role in this process indicating stages of the world partial reconstruction including settlements paradigm, redefining of current urban planning typology, natural resource saving, new ethics, aesthetics and design techniques based on the wide range of instrumental means from XX century scientific and industrial style actualization to nanotechnology. Something absolutely new such as flexible hybrid systems immediately responding to new challenges will distinguish features of the third global «superstyle». Movement towards this will require a transition period to provide safety of the current vital activity with the conversion to architectural and urban planning systems.Architecture specialists educating will require study process modernization advanced techniques. Sebastian Eimar maintains that the crisis of that kind will provoke a global review of architects work. He proposes that the shock caused by the trivial virus warns the mankind to be prepared for more severe crisis [21].

\section{References}

1. B. Colomina, X-Ray Architecture, Lars Müller Publishers, 200, 34 (2019)

2. G. N. Aidarova, D. A. Kulikov, K ponjatiju resurso sberegajushhaja arhitektura (To the concept of resource-saving architecture), Izvestia KGASU, 2(6), 5-7 (2006)

3. G. N. Aidarova, E.Bashirova, Regional architecture of Russia: Kazan - conflicts of the «old» and «new», IOP Conf. Ser.: Mater. Sci. Eng. 890, 012016 (2020) DOI: 10.1088/1757-899X/890/1/012016

4. D. Koch, Changing building typologies: The typological question and the formal basis of architecture (School of Architecture and the Built Environment KTH Royal Institute of Technology, Stockholm, 168-189, 2014)

5. R. Levitas, Utopia as Method The Imaginary Reconstitution of Society University of Bristol, UK, Palgrave Macmillan, 268, 13-15 (2013)

6. Peter Cook, Beyond Archigram: Towards a Critical Utopianism, Prostor, 1(59), 28, 130-141 (2020)

7. E. A. Goldzamt, Uil'jam Morris i social'nye istoki sovremennoj arhitektury (William Morris and the Social Origins of Modern Architecture) (trans. from Polish G. A. Guryanova, Stroyizdat, Moscow, Russia, 172, 17-21, 1973)

8. A. Byers, P. Stapleton, Biopolitics and Utopia, Palgrave Macmillan, 210, 44-45 (2015)

9. Jean-Luc Nancy, In Place of Utopia. In Existential Utopia: New Perspectives on Utopian Thought (Continuum, New York, 192, 95, 2012) 
10. V. Stanescu, «Green Eggs and Ham? The Myth of Sustainable Meat and the Danger of the Local» Critical Theory and Animal Liberation (Rowman and Littlefield, Plymouth, UK, 239-255, 2011)

11. B. I. Cannon, Staging Urban Landscapes: The Activation and Curation of Flexible Public Spaces, Hardcover, 304, 34-3 (2018)

12. M. S. Zarrabi, A. Yazdan far, S. B. Hosseini, COVID-19 and heal thy home preferences: The case of apartment residents, Tehran Journal of Building Engineering 35, 3 (2021)

13. L. Acharya, Flexible architecture for the dynamic societies. Reflection on a Journey from the 20th Century into the Future, Master's thesis in Art History Faculty of Humanities, Social Sciences and Education University of Tromsøv, 94, 15 (2013)

14. D. Torben, Climate and Architecture, The Royal Danish Academy of Fine Arts, School of Architecture Publishers, 164, 54-58 (2010)

15. J. G. Mastalerczyk, The Place and Role of Religious Architecture in the Formation of Urban Space, Procedia Engineering, 161, 53-57 (2016)

16. T. Cresswell, P. Merriman, Geographies of Mobilities: Practices, Spaces, Subjects (Ashgate Publishing Ltd, Farnham, 288, 144, 2011)

17. F. L. Wright, Ischezajushhij gorod (The Disappearing City) (Strelka-Press, Moscow, 180, 33, 2016)

18. S. S. Zhuikov, Tretij global'nyj stil' kak al'ternativnyj scenari razvitija arhitektury (The third global style as an alternative scenario for the development of architecture), The third global style as an alternative scenario for the development of architecture, Novye idei novogo veka, IAS TOGU, 37-41(2011)

19. N.F. Metlenkov, Paradigmal'naja dinamika arhitekturnogo metoda (Paradigmatic dynamics of the architectural method) (ASROS, Moscow, 428, 285-286, 2018)

20. A. Krasheninnikov, Cognitive Urban Studies, Kurs, 210, 84-86 (2020)

21. S. Eimar Chto ozhidaet mir arhitektury posle pandemii? (What awaits the world of architecture after the pandemic?), ARCH Moskva - official site [Electronic resource]. Access mode: http://www.archmoscow.ru/novosti/sebastyan-ejmar:-chto-ozhidaet-mirarxitekturyi-posle-pandemii-.html (access date 12/15/2019) 